\title{
DEVELOPMENTS OF DIGESTIVE TRACT IN LARVAE OF CLIMBING PERCH, Anabas testudineus (Bloch)
}

\author{
Yulintine ${ }^{*}$ \#, Enang Harris ${ }^{* * *}$, Dedi Jusadi ${ }^{* * *}$, Ridwan Affandi ${ }^{* * * *}$, and Alimuddin ${ }^{* * *}$ \\ *) Postgraduate student of Aquaculture Department, Bogor Agricultural University, Bogor \\ *) Aquaculture Department, Bogor Agricultural University, Bogor \\ ${ }^{* * *)}$ Aquatic Resource Management Department, Bogor Agricultural University, Bogor
}

(Received 21 July 2010; Accepted 1 December 2010)

\begin{abstract}
Climbing perch, Anabas testudineus (Bloch) is a potential species for aquaculture in Kalimantan, Indonesia and belongs to Anabantidae family. The development of its digestive tract was evaluated on larvae reared under culture conditions of $28^{\circ} \mathrm{C}$ $30^{\circ} \mathrm{C}$, from hatching to 30 days after hatching using histological and morphological methods. The larvae were kept in six 100-L tanks. They were fed with rotifers and microalgae from day $2^{\text {nd }}$ after hatching to day $10^{\text {th }}$; Artemia nauplii from day $7^{\text {th }}$ to day $15^{\text {th }}$; Artemia meta-nauplii from day $15^{\text {th }}$ to day $20^{\text {th }}$; and Tubifex worm from day $20^{\text {th }}$ onwards. The development of digestive tract in climbing perch followed the general pattern described for other species. Shortly after hatching, its digestive system was found to be consisted of an undifferentiated straight tube laying dorsally to the yolk sac. At first feeding (day $2^{\text {nd }}$ ), both mouth and anus had opened and the yolk sac was partially absorbed. On day 3 , the digestive tract was fully differentiated into buccopharynx, esophagus, intestine and rectum. The two pyloric caeca appeared on day $25^{\text {th }}$ after hatching, indicating the transition from larval to juvenile stage and acquisition of an adult type of digestion.
\end{abstract}

KEYWORDS: digestive tract, larvae, development, climbing perch

\section{INTRODUCTION}

Larval nutritional studies have been receiving much attention because an understanding of changes associated with the processes of food ingestion, digestion, and assimilation are the initial steps in determining the ability of larvae to utilize a given diet (Martinez et al., 1999). The high rates of mortality reported during small larval fish culture have been blamed to inadequate larval nutrition. A change in the source of nutrition will occur during larval development. In the first day, its endogenous is sourced from the yolk sac and oil glob- ule. Once the endogenous reserves are all absorbed, food must be obtained from an exogenous source. At the time of the first feeding, the larval digestive tract is not fully developed (Micale et al., 2006) so that small larval rearing is based primarily on the use of live prey during early development of larvae from two to several weeks.

A detail understanding of the development of the digestive tract of fish larvae may contribute to the increase of the larval rearing success. This gut ontogeny study is an initial step in identifying and implementing new feed

\# Corresponding author. Aquaculture Study Program of Faculty of Agriculture, University of Palangka Raya, Central Kalimantan, Indonesia. Tel.: + 625363228524

E-mail address: pojok_bangas@yahoo.com 
alternatives for small fish larvae. Together with digestive enzymatic study, it can determine the best time to initiate early weaning of the larvae. This practice may result in substantial cost savings in live food production. Several commercially valuable species have been studied, including seabass (Walford \& Lam, 1993), gilthead seabream (Sarasquete et al., 1995), spotted sand bass (Pena et al., 2003), California halibut (Gisbert et al., 2004), yellowtail kingfish (Chen et al., 2006), goldlined seabream (Ibrahim et al., 2006), common pandora (Micale et al., 2006), and percula clownfish (Onal et al., 2008). However, little information is available regarding the digestive tract development in larvae of tropical freshwater fish species.

The climbing perch (A. testudineus) is a member of anabantoid fish and has a potential to be cultured in Kalimantan. It has been successfully reared under controlled laboratory conditions until adult stage (Phuong et al., 2001; Widodo et al., 2007), but high larval mortality has been reported (Trieu \& Long, 2001; Morioka et al., 2009). Therefore, the objective of this study was to describe the ontogenetic development of the digestive tract of climbing perch larvae under culture conditions, for the purpose of improving feeding strategies during this developmental stage.

\section{MATERIAL AND METHODS}

Larvae used in the present study were obtained from an artificial spawning of $A$. testudineus broodstock ( 3 females and 6 males) of climbing perch in the laboratory of Aquaculture Department, Bogor Agricultural University. Newly hatched larvae were placed in three $100-\mathrm{L}$ tanks with water temperature of $28^{\circ} \mathrm{C}$ $30^{\circ} \mathrm{C}$. Larvae were fed for the first time at day $2^{\text {nd }}$ after hatching until day $10^{\text {th }}$ after hatching with rotifers (Brachionus calyciflorus) and microalgae. From day $7^{\text {th }}$ to $15^{\text {th }}$, the fish were fed with newly Artemia nauplii, and then continued fed with Artemia meta-nauplii until day $20^{\text {th }}$ after hatching. Tubifex worms were used as live preys from day $20^{\text {th }}$ to day $30^{\text {th }}$ post hatching.

A hundred larval samples were taken from the rearing tanks on day $0-5^{\text {th }}, 8^{\text {th }}, 12^{\text {th }}, 16^{\text {th }}$, $20^{\text {th }}, 25^{\text {th }}$, and $30^{\text {th }}$ after hatching to measure their total length and mouth size using a microscope connected to a digital camera. The samples (10 larvae) were fixed using Bouin's solution before further analysis. For each sampling day, a fixed larvae sample was dehydrated with a graded series of ethanol (70\% $100 \%)$. The larvae were embedded in paraffin. Sagital sections (3-5 $\mu \mathrm{m}$ thick) were obtained with a microtome and stained with haematoxylin-eosin for general acidophilic and basophilic histological features. Slides were also stained by periodic acid-Schiff (PAS) for neutral mucosubstances. Observations using light microscope were performed using different magnifications to describe the development of the digestive tract.

\section{RESULT AND DISCUSSION}

\section{Results}

\section{Morphology}

At hatching (day $0, \mathrm{HO}$ ), the total length of yolk sac larvae was $2.12 \pm 0.16 \mathrm{~mm}(n=100)$ (Fig. 1) and reached 17.64 $\pm 3.79 \mathrm{~mm}(n=100)$ on day $30^{\text {th }}$. At HO, the alimentary canal appeared as a straight tube lying dorsally to the yolk sac. The mouth and anus were closed. At day $1^{\text {st }}$ to day $2^{\text {nd }}$ after hatching, yolk-sac absorption was very fast and the digestive system of climbing perch underwent further differentiation and the rudimentary alimentary canal became segmented into four different regions: the buccopharynx, esophagus, intestine, and rectum. All of the larvae opened mouths about 34-36h after hatching, with the mouths measuring $0.38 \pm 0.03 \mathrm{~mm}$ in height. At day $2^{\text {nd }}$ after hatching $(\mathrm{H} 2)$ with total length $3.03 \pm 0.30 \mathrm{~mm}, \mathrm{n}=100$, the mouth had opened and exogenous feeding began. At the same day, the eyes were pigmented. Growth of climbing perch larvae followed an exponential curve (Fig. 2).

From day $2^{\text {nd }}$ after hatching the swim bladder started to be inflated. At day $5^{\text {th }}$ after the first feeding, the yolk sac was almost completely reabsorbed. At day $12^{\text {th }}$ after hatching with total length of $5.46 \pm 0.89 \mathrm{~mm}$, larvae started to change its morphology to be similar to adult type and metamorphosis processes were completed around day $25^{\text {th }}$ after hatching for most of the larvae. Moreover, two pyloric caeca appeared at day $25^{\text {th }}$ after hatching, indicating the transition from larval to juvenile stage and acquisition of an adult type of digestion. 

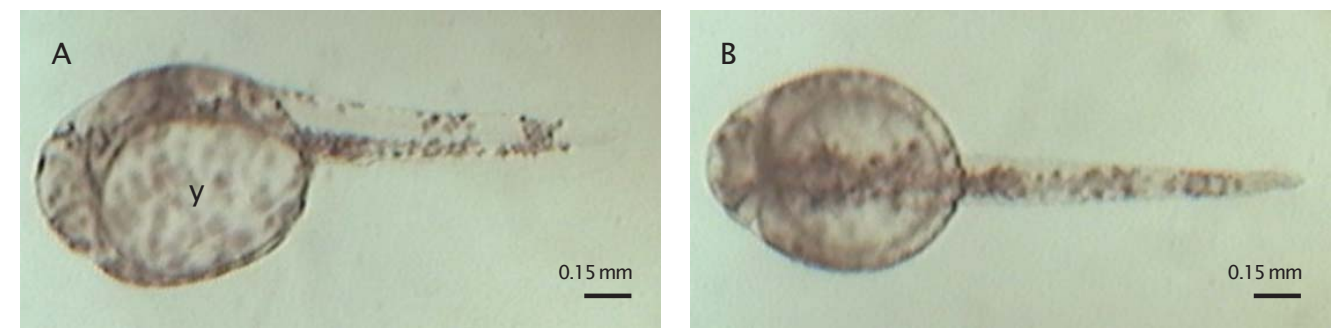

A. ventrally view; B. Dorsally view; y = yolk; $100 \mathrm{X}$

Figure 1. Newly hatched larva Anabas testudineus with average total length $2.12 \pm 0.16 \mathrm{~mm}$, $n=100$

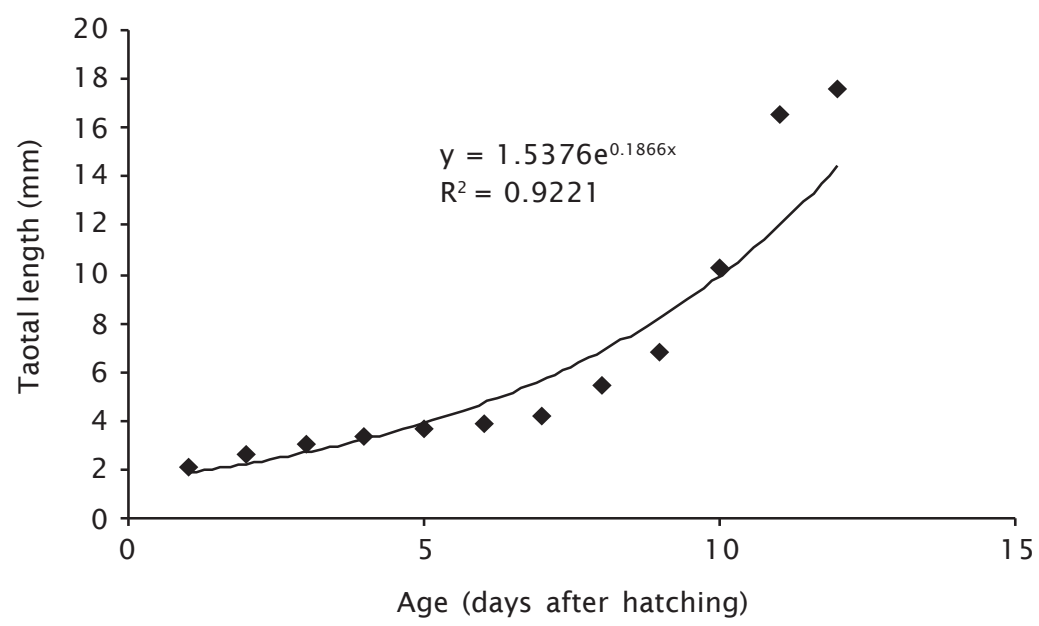

Figure 2. Average total length ( $\mathrm{mm}$ ) of $A$. testudineus larvae. The arrow indicates the time of first feeding at day 2 after hatching

\section{Histology}

\section{- Buccopharynx}

Between day $1^{\text {st }}$ and $2^{\text {nd }}$ after hatching, the mouth opened. The buccopharyngeal epithelium was composed of a single layer of squamous cells. Chondrocytes of the rudimentary gill arches were visible under the epithelium of the posterior buccopharynx (Fig. 3). At day $12^{\text {th }}$ after hatching the goblet cells appeared PAS positive (Fig.4B). Oral and tongue taste buds as well as buccal goblet cells became evident among epithelial cells from day $25^{\text {th }}$ after hatching (Fig. 4C). Taste buds and goblet cells became more numerous as larvae grew.

\section{- Oesophagus and stomach}

At day $2^{\text {nd }}$ after hatching, the buccopharynx channeled with the anterior intestine through a short oesophagus with a rather narrow lumen (Fig. 4A). At day $16^{\text {th }}$ after hatching, the stomach exhibited a pouched shape (Fig. $5 \mathrm{~A}$ ) and it began well developed at day $20^{\text {th }}$ after hatching (Fig. 5B). At day $30^{\text {th }}$ (total length $17.64 \pm 3.79 \mathrm{~mm}$ ), two pyloric caeca were also observed.

\section{- Intestine}

With the beginning of exogenous feeding, the lumen of the anterior intestine dilated and small. At day $12^{\text {th }}$ after hatching mucosal folding appeared well developed in the anterior and posterior intestines (Fig. 6A). At day $30^{\text {th }}$ after hatching, mucosal folding of the anterior and posterior intestines appeared very prominent (Fig. 6B). PAS positive goblet cells appeared distributed between enterocytes of both anterior and posterior intestines from day $30^{\text {th }}$ after hatching (Fig. 6C, D). 


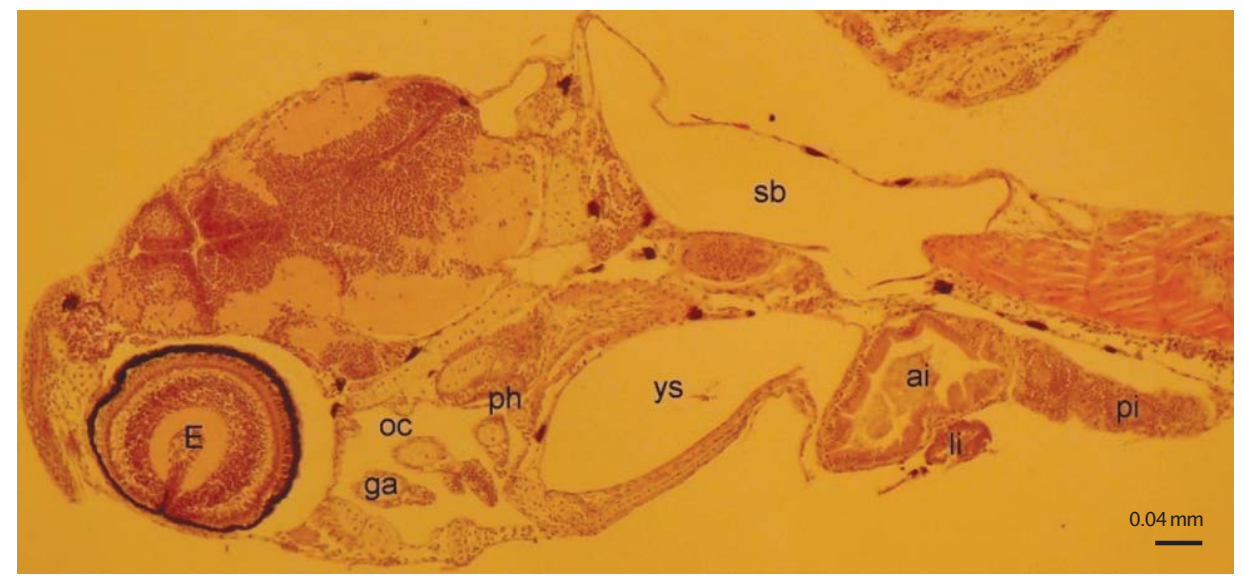

Figure 3. Sagittal sections of the gastro-intestinal tract of climbing perch larvae at day 2 after hatching showing differentiation of oral cavity (oc), pharynx (ph), anterior intestine (ai) and posterior intestine (pi), HE, 100X; yolk sac (ys), eye (E), gill arch (ga), liver (li), swim bladder (sb)
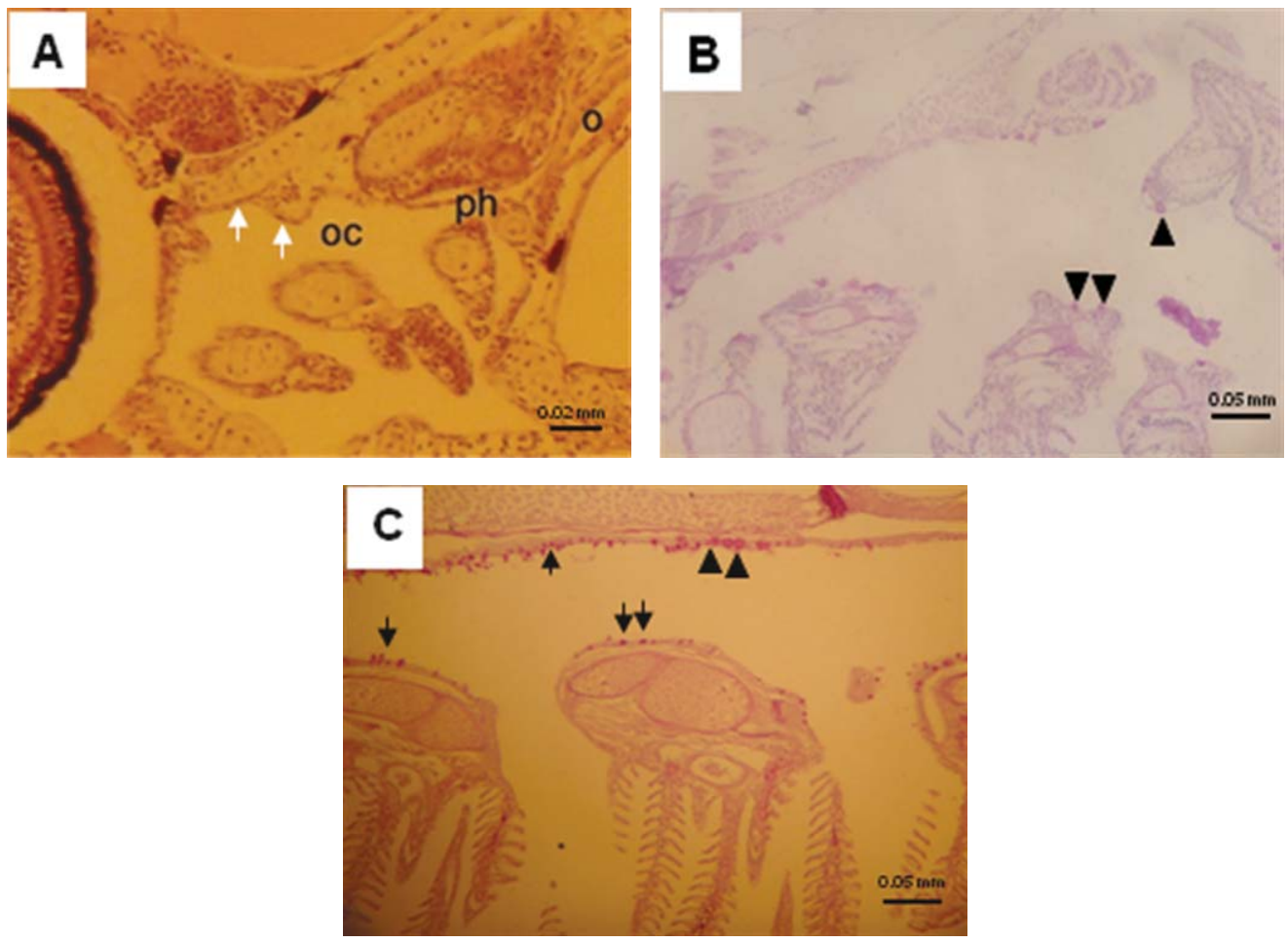

Figure 4. (A) Detail of pharyngeal epithelium at day 2 after hatching of climbing perch larvae (white arrows); HE, 400X. (B) Detail of pharyngeal epithelium at day 12 after hatching larvae showing functional goblet cell (arrowheads); PAS, 200X. (C) Detail of pharyngeal epithelium at day 25 after hatching larvae showing goblet cells (arrowheads) and taste buds (arrows); PAS, 200X; oral cavity (oc), gill arch (ga), pharynx (ph), oesophagus (o) 

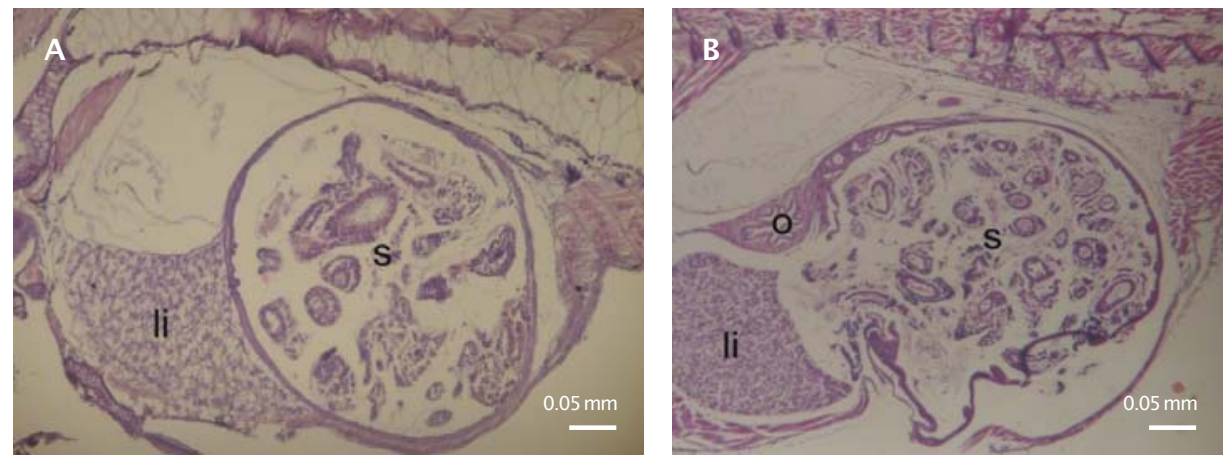

Figure 5. Sagittal sections of stomach of climbing perch larvae at (A) day 16 after hatching. (B) day 20 after hatching showing well development; HE, 200X; stomach (s), liver (li), oesophagus (o)
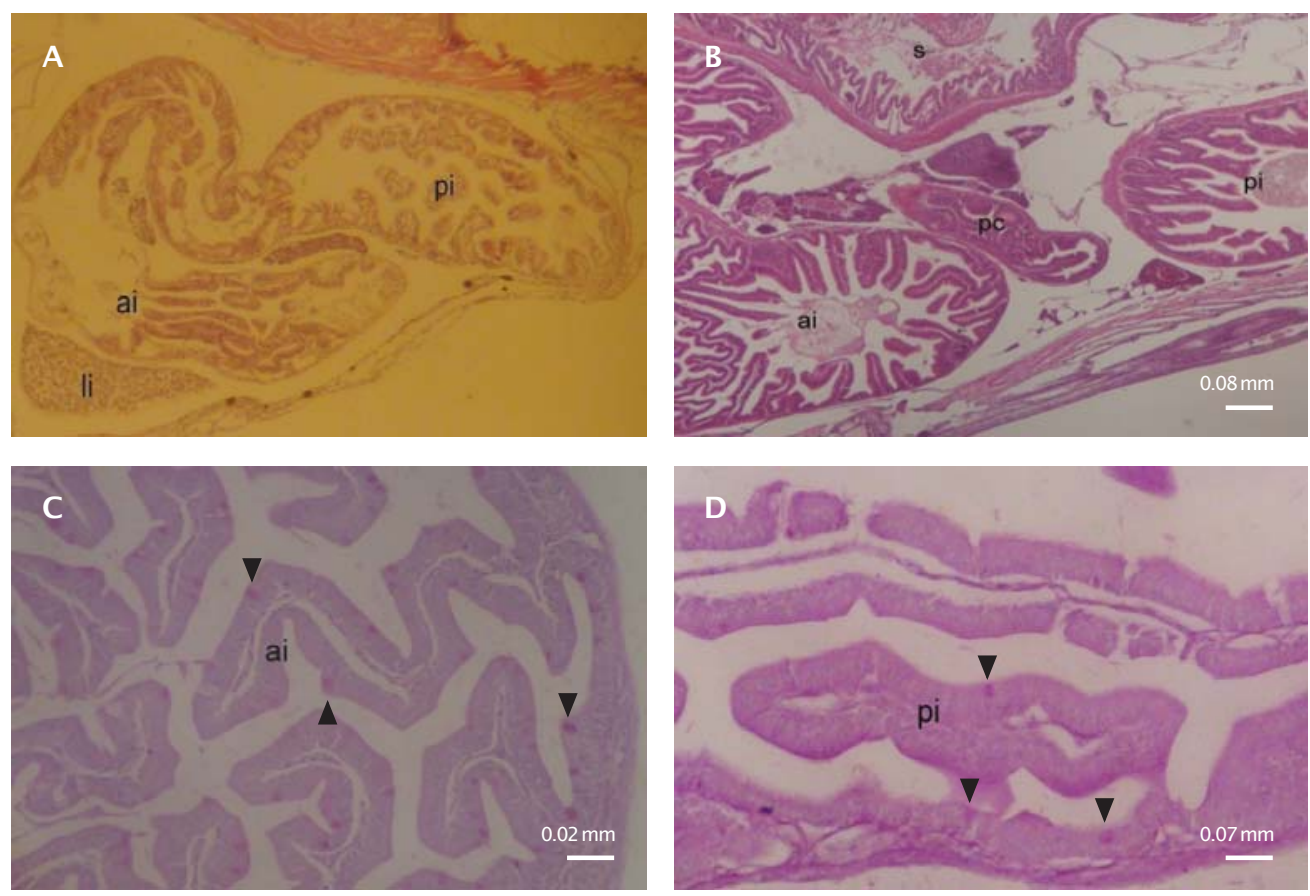

Figure 6. Detail of intestine of larvae at (A) day 12 after hatching showing mucosal folding well developed in the anterior and posterior intestine; HE, 200X. (B) day 30 after hatching showing very prominent mucosal folding; HE, 200X. (C, D) day 30 after hatching with scattered functional goblet cell (arrowheads); PAS, 400X and 600X; liver (li), anterior intestine (ai), posterior intestine (pi), stomach (s), pyloric caecum (pc)

\section{- Liver, pancreas and gall bladder}

At hatching, the accessory digestive organs were absent. Liver increased in size after hatching and extended into the space of diminishing yolk sac with the hepatocytes becoming polyhedral and proliferation of the sinusoids (Fig. 7A). Two types of cytoplasmic inclusions were apparent within hepatocytes by day $12^{\text {th }}$ after hatching: eosinophilic, PAS positive granules and colorless, PAS-negative vacuoles (Fig. 7B). The latter progressively in- 
creased in size with larval growth, occupying most of the cytoplasm. At day $2^{\text {nd }}$ after hatching, the incipient pancreas could be detected between liver and intestine, while gall bladder could be detected between liver and the yolk sac wall (Fig. 7A). At day $3^{\text {rd }}$ after hatching, the endocrine cells irregularly shaped with pale cytoplasm and large nucleus, were distinguished as islets of Langerhans inside the exocrine pancreas (Fig. 7D) and well developed by day $20^{\text {th }}$ after hatching (Fig. 7D).

\section{Discussion}

Significant changes occurred in the digestive tract of climbing perch larvae during the first several days of development. At hatching, the digestive tract of the larvae was undifferentiated straight tube and rudimentary, similar to the most other fish species reported such as seabass (Walford \& Lam, 1993), gilthead seabream (Sarasquete et al., 1995), spotted
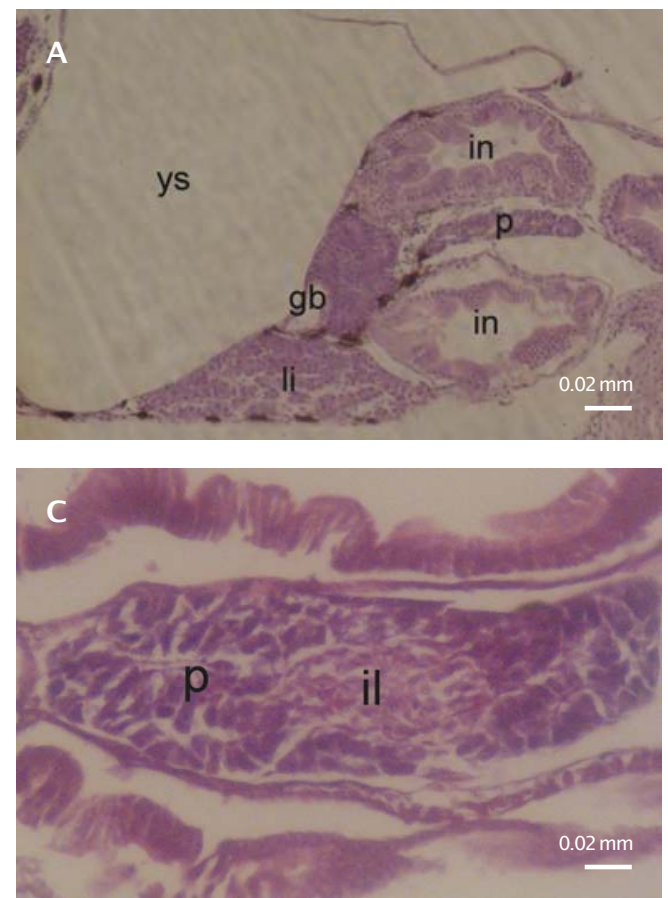

sand bass (Pena et al., 2003), California halibut (Gisbert et al., 2004), yellowtail kingfish (Chen et al., 2006), goldlined seabream (Ibrahim et al., 2006), and common pandora (Micale et al., 2006). Differentiation of the digestive tract of climbing perch larvae into four distinct regions, namely, buccopharynx, oesophagus, intestine, and rectum, was established within day $2^{\text {nd }}$ after hatching coinciding with time of the first feeding.

From hatching until to 2 days old, climbing perch larvae depended extremely on an endogenous source of nutrition. According to Heming \& Buddington (1988), endogenous nutrition in fish larvae occurred by endocytosis of yolk sac and oil globule through a syncytium surrounding the yolk sac. However, exogenous feeding in climbing perch larvae started before complete re-absorption of yolk sac, as demonstrated by the presence of rotifers and microalgae in the digestive tract by
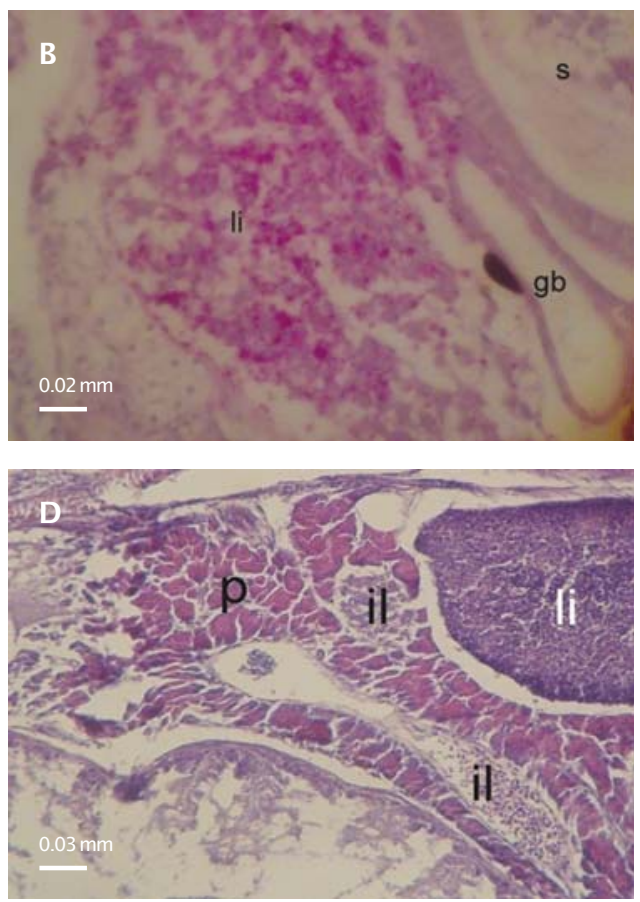

Figure 7. Sagittal sections of climbing perch larvae liver at (A) day 2 after hatching showing gall bladder; HE, 100X. (B) day 12 after hatching showing polygonal hepatocytes containing extensive vacuoles; PAS positive, eosinophilic granules; PAS-negative, colourless vacuoles, 400X. Sagittal section of climbing perch larvae pancreas at (C) day 2 after first feeding showing endocrine cells (islet of Langerhans); HE, 400X, and (D) day 20 after hatching showing well developed; HE, 200X; gall bladder (gb), intestine (in), liver (li), yolk sac (ys), islet Langerhan (il), pancreas (p), swim bladder (sb) 
day $2^{\text {nd }}$ after hatching. The use of microalgae and rotifers seemed to be essential during the first stage of climbing perch larvae rearing as well as of the larvae. Indeed, phytoplankton may act as a diet component and/or stimulating factor of digestive enzyme synthesis providing positive effect to the larvae (Reitan et al., 1993).

The liver and pancreas of climbing perch differentiated early in the development process. Two or three days after the first feeding, the presence of pancreas with endocrine cells (islets Langerhans), the larvae may secrete many pancreatic enzymes such as alkaline proteases, amylase, and lipase contributing digestion and absorption of proteins, lipids, and carbohydrates. Moreover, at day $12^{\text {th }}$ after hatching the liver showed a PAS positive reaction with eosinophilic granules as a sign of glycogen deposit indicating functional hepatocytes, whereas the liver showed a PAS negative reaction with colorless vacuoles as a sign of lipid deposit. Boulhic \& Gabaudan (1992) suggested that the presence of granules in the enterocytes related to glycogen absorption.

The functional PAS-positive mucous cells in the digestive tract of climbing perch larvae were detected in the pharyngeal and oesophageal epithelium on day $12^{\text {th }}$ after hatching. The late appearance of mucous secretion has been also reported in gilthead seabream (Sarasquete et al., 1995), and California halibut (Gisbert et al., 2004). Glycoproteins produced by goblet cells may play an important lubricant role of the buccopharyngeal and oesophageal mucosa due to lack of salivary glands. Mucosubstances may play important role in protecting digestive mucosa from viral and bacterial attacks (Gisbert et al., 2004).

Intestinal coiling (on day $3^{\text {rd }}$ after hatching) and mucosal folding (on day $12^{\text {th }}$ after hatching) began at a rather early stage and appeared very pronounced in both the anterior and posterior intestines by day $30^{\text {th }}$ after hatching, indicating a better functionality of the gut by the increase of intestinal length and absorption surface. In addition, two pyloric caeca were detected by day 25 after hatching, indicating the presence of functional stomach. Finally, based on the present histological and morphological data, climbing perch larvae could be weaned to formulated feeds on day $25^{\text {th }}$ after hatching.

\section{ACKNOWLEDGEMENTS}

The authors would like to thank Mr. Manawam and Mr. Dedi for their support during larvae culture. This study was funded by the IMHERE Unpar, DIKTI and supported by the IPB.

\section{REFERENCES}

Boulhic, M. \& Gabaudan, J. 1992. Histological study of the organogenesis of the digestive system and swim bladder of the dover sole, Solea solea (Linnaeus, 1758). Aquaculture, 102: 373-396.

Chen, B.N., Qin, J.G., Kumar, M.S., Hutchinson, W., \& Clarke, S. 2006. Ontogenetic development of the digestive system in yellowtail kingfish Seriola lalandi larvae. Aquaculture, 256: 489-501.

Gisbert, E., Piedrahita, R.H., \& Conklin, D.E. 2004. Ontogenetic development of the digestive system in California halibut (Paralichthys californicus) with notes on feeding practices. Aquaculture, 232: 455-470.

Heming, T.A., \& Buddington, R.K. 1988. Yolk absorption in embryonic and larval fishes. In :Fish Physiology. Vol. XI Part A. Eds. Hoar WS, Randall DJ, Brett JR, Academic Press. London, p. 407-466.

Ibrahim, F.S., Rana, K.J., Goddard, J.S., \& Al Amri, I.S. 2006. Morphological development of post hatch larval goldlined seabream Rhabdosargus sarba (Forskal, 1775). Aquaculture Research, 37: 1,156-1,164.

Martinez, I., Moyano, F.J., Fernandez, C., \& Yufera, M. 1999. Digestive enzyme activity during larval development of the Senegal sole (Solea senegalensis). Fish Physiol. Biochem., 21: 31 7-323.

Micale, V., Garaffo, M., Genovese, L., Spedicato, M.T., \& Muglia, U. 2006. The ontogeny of the alimentary tract during larval development in common pandora Pagellus erythrinus L. Aquaculture, 251 : 354-365.

Morioka, S., Ito, S., Kitamura, S., \& Vongvichith, B. 2009. Growth and morphological development of laboratory-reared larval and juvenile climbing perch Anabas testudineus. Ichthyological Research, 56(2): 162171.

Onal, U., Langdon, C., \& Celik, I. 2008. Ontogeny of the digestive tract of larval percula clownfish, Amphiprion percula (Lacepede 1802): a histological perspective. Aquaculture Research, 39: 1,077-1,086. 
Pena, R., Dumas, S., Villalejo-Fuerte, M., \& OrtizGalindo, J.L. 2003. Ontogenetic development of the digestive tract in reared spotted sand bass Palalabrax maculatofasciatus larvae. Aquaculture, 219: 633-644.

Phuong, N.T., Liem, P.T., Toan, V.T., Hien, T.T.T., $\&$ Van Tinh, L. 2001 . Study on the effects of feeding diets on growth of climbing perch (Anabas testudineus) cultured in garden ditches. In: Proceeding of the 2000 annual workshop of JIRCAS Mekong Delta Project, p. 243-247.

Reitan, K.I., Rainuzzo, J.R., Øie, G., \& Olsen, Y. 1993. Nutritional effects of algal addition in first-feeding of turbot (Scophtalmus maximus L.) larvae. Aquaculture, 118 : 257 275.

Sarasquete, M.C., Polo, A., \& Yufera, M. 1995. Histology and histochemistry of the development of the digestive system of larval gilthead seabream Sparus aurata L. Aquaculture, 130: 79-92.
Trieu, N.V., \& Long, D.N. 2001. Seed production technology of Climbing perch (Anabas testudineus): A study on the larval rearing. In : Proceeding of the 2000 annual workshop of JIRCAS Mekong Delta Project, p. 199202.

Walford, J., \& Lam, T.J. 1993. Development of digestive tract and proteolytic enzyme activity in seabass (Lates calcarifer) larvae juveniles. Aquaculture, 109: 187-205.

Widodo, P., Bunasir, Fauzan, G., \& Syafrudin. 2007. Kaji terap pembesaran ikan papuyu (Anabas testudineus Bloch) dengan pemberian kombinasi pakan pelet dan keong mas dalam jaring tancap di perairan rawa. Balai Budidaya Air Tawar Madiangin. Banjarmasin: Direktorat Jenderal Perikanan Budidaya. Departemen Kelautan dan Perikanan, p. 1-26. 